\title{
Ganaya:
}

Jurnal Thme Sasial dan \#umaniora Jayapangus Press

http://jayapanguspress.penerbit.org/index.php/ganaya Vol. 4 No. 2 (2021)

\section{Central-Local Government dalam Manajemen Bencana Pandemi COVID-19 di Indonesia}

\author{
Rumzi Samin \\ Program Magister Administrasi Publik, Universitas Maritim Raja Ali Haji \\ rumzisamin@umrah.ac.id
}

\begin{tabular}{l} 
Keywords: \\
\hline Central-Local \\
Goverment; \\
Management; \\
Disaster; \\
COVID-19 \\
\hline
\end{tabular}

\begin{abstract}
The relationship between the local government and the central government in handling COVID 19 in Indonesia is considered very bad because the existing disaster management is considered slow in breaking the chain of the spread of COVID 19. The purpose of this study focuses on coordination between the central government and local governments where there are many mismatched statements in determining policies in handling COVID 19. The research method uses a systematic literature review (systematic literature review) is one approach to the literature review method by describing the procedure for selecting publication criteria and/or literature that is reviewed with the aim of getting a broad picture related to a particular topic or issue. The results of the study indicate the need for the principles of interaction of local and central government authorities in the assignment of handling the COVID-19 disaster that has not used a good disaster management strategy, this is because it does not implement the relationship responsibility principles of central-local government interaction so it is necessary to strengthen communication. In addition, during the COVID-19 pandemic, there is a complicated bureaucratic system in central-local government interactions.
\end{abstract}

Kata Kunci:

Pemerintah

Pusat-Daerah;

Manajemen;

Bencana;

COVID-19

\begin{abstract}
Abstrak
Hubungan pemerintah daerah dan pemerintah pusat dalam penanganan COVID 19 di indonesia dinilai sangat buruk, dikarenakan manajemen bencana yang telah ada di anggap lambat dalam memutuskan rantai penyebaran COVID 19. Tujuan dari Penelitian ini memfokuskan pada koordinasi antara pemerintah pusat dan pemerintah daerah dimana banyak ketidakcocokan pernyataan dalam menentukan kebijakan dalam penanganan COVID 19. Metode penelitian mengunakan kajian literatur sistematis (systematic literature review) merupakan salah satu pendekatan metode kajian literatur dengan memaparkan prosedur pemilihan kriteria publikasi dan/atau literatur yang dikaji dengan tujuan untuk mendapat gambaran
\end{abstract}


yang luas terkait topik atau isu tertentu. Hasil penelitian menujukan perlu adanya prinsip-prinsip interaksi kewenangan pemerintah daerah dan pusat dalam penugasan penanganan bencana COVID-19 belum mengunakan strategi manajemen bencana yang baik, hal ini dikarenakan tidak mengimplementasikan pada tanggungjawab hubungan prinsipprinsip interaksi central-local goverment sehingga perlu adanya penguatan komunikasi. Selain itu dalam masa pendemi COVID19 mempunyai sistem birokrasi yang rumit pada interaksi central-local goverment.

\section{Pendahuluan}

COVID-19 berdampak pada perekonomian dunia yang semakin meningkat. Sehingga pandemic ini akan membuat perekonomian dunia hilang + US\$ 1 triliun dan pertumbuhan ekonomi dunia di bawah $2 \%$, jauh di bawah prediksi sebelumnya yang mencapai 2,5\% (Modji, 2020; Putra \& Handoko, 2021). Hal tersebut berdampak pada roda perekonomian dunia kemudian kesiapan setiap negara didalam menanggulagi COVID-19, termasuk Indonesia. Namun saat ini, dibeberapa negara berkembang Pemerintah Pusat dan Pemerintah Daerah kewalahan dalam menghadapi COVID-19 (Dzigbede et al, 2020; Adhikari \& Budhathoki, 2020; Tangcharoensathien et al, 2021).

Dalam konteks pandemi COVID-19, kondisi kerja tenaga kesehatan dapat memburuk. Selain risiko infeksi COVID-19, tenaga kesehatan terus mengalami risikorisiko kesehatan dan keselamatan kerja lain yang bersifat biologis, fisik, maupun psikososial. Karena itu, untuk melindungi kesehatan, keselamatan, dan kesejahteraan fisik dan jiwa tenaga kesehatan, WHO merekomendasikan serangkaian langkah pencegahan dan pengendalian infeksi, kesehatan dan keselamatan kerja, dan dukungan psikososial yang harus dilakukan oleh pemerintah pusat maupun pemerintah daerah.

Pemerintah Daerah kesulitan mengungkap dan melacak kasus positif COVID-19 di wilayahnya lantaran pemerintah pusat tidak menyampaikan data tersebut ke pemerintah daerah sehingga tidak adanya sinkron antara kebijakan nasional dengan inisiatif pemerintah lokal (Anderson et al, 2019). hal tersebut tidak sesuai dengan Perka BNPB 10 tahun 2008 tentang Pedoman Komando Tanggap Darurat Bencana. Karena Penanganan penyebaran COVID-19 membutuhkan pendekatan integralistik antar wilayah mengingat interaksi antar manusia begitu luas dan multi segmen. Penanganan penyebaran virus COVID-19 membutuhkan pendekatan integralistik antar wilayah mengingat interaksi antar manusia begitu luas dan multi segmen (Setiawan \& 
Mahadiansar, 2020). Pemerintah Pusat dan daerah melakukan kesiapan sistem perawatan kesehatan harus secara efektif (MacLaren, et al, 2020).

Menurut Carter (2008) definisi manajemen bencana adalah suatu kejadian, alam atau buatan manusia, tiba- tiba atau progesive, yang menimbulkan dampak yang dasyat (hebat) sehingga komunitas (masyarakat) yang terkena atau terpengaruh harus merespon dengan tindakan-tindakan luar biasa. Menurut UU No. 24 Tahun 2007 Tentang Penggulangan Bencana Bab I Pasal 1 ayat 1, Bencana adalah peristiwa atau rangkaian peristiwa yang mengancam dan mengganggu kehidupan dan penghidupan masyarakat yang disebabkan, baik oleh faktor faktor manusia sehingga alam dan/atau faktor non alam maupun mengakibatkan timbulnya korban jiwa manusia, kerusakan lingkungan, kerugian harta benda, dan dampak psikologis.

Pada ayat 2,3 dan 4 bencana dibedakan atas 3 kategori berdasarkan penyebabnya, yaitu bencana alam, bencana non alam, dan bencana sosial. Bencana alam adalah bencana yang diakibatkan oleh peristiwa atau serangkaian peristiwa yang disebabkan oleh alam antara lain berung gempa, bumi, tsunami, gunung meletus, banjir, kekeringan, angin topan, dan tanah longsor. Bencana non alam adalah bencana yang diakibatkan oleh peristiwa atau rangkaian peristiwa nonalam yang antara lain berupa gagal teknologi, gagal modernisasi, epidemi, dan wabah penyakit (Husein, 2014). Bencana sosial adalah bencana yang diakibatkan oleh peristiwa atau serangkaian peristiwa yang diakibatkan oleh manusia yang meliputi konflik sosial antar kelompok atau antar komunitas masyarakat, dan teror (Tierney, 2012; Lee et al, 2016).

Mengacu pada definisi bencana dalam buku Disaster Management : A Disaster Manager's Handbook dan UU No. 24 Tahun 2007 Tentang Penggulangan Bencana Bab I Pasal 1 ayat 1 serta beberapa beberapa kamus bencana atau disaster maka bencana merupakan suatu kejadian atau serangkaian peristiwa berupa gangguan atau kekacauan yang disebabkan, baik oleh faktor alam dan/atau faktor nonalam maupun faktor manusia pada pola normal kehidupan yang mengancam dan mengganggu kehidupan dan penghidupan masyarakat sehingga mengakibatkan timbulnya korban jiwa manusia, kerusakan lingkungan, kerugian harta benda, dan dampak psikologis. Gangguan atau kekacauan ini biasanya hebat, terjadi tíba-tiba, tidak disangka dan wilayah cakupan cukup luas. Kemudian Rahmi \& Satria (2013) Manajemen dapat berarti pencapaian suatu tujuan melalui pelaksanaan fungsi-fungsi tertentu, tetapi dalam hal ini belum ada kesamaan pendapat dari para ahli manajemen tentang fungsi-füngsi tersebut. 
Sebenarnya apabila dicermati maka manajemen mempunyai empat fungsi pokok, yaitu fungsi perencanaan, pengorganisasian, pelaksanaan dan fungsi pengawasan. Pengelolaan bencana didefinisikan sebagai suatu ilmu pengetahuan terapan (aplikatif) yang mencari, dengan observasi sistematis dan analisis bencana untuk meningkatkan tindakan-tindakan (measures) terkait dengan preventif (pencegahan), mitigasi (pengurangan), persiapan, respon darurat dan pemulihan. Langkah utama dan fungsi pengelolaan atau manajemen secara umum termasuk dalam pengelolaan bencana meliputi: Perencanaan, Pengorganisasian, Kepemimpinan, Pengkoordinasian, Pengendalian, Pengawasan, Penganggaran, dan Keuangan (Grigg, 1988).

Hubungan Pemerintah daerah dan pemerintah Pusat di negara-negara demokratis bergantung pada apakah kendali politik yang sama berkuasa secara daerah maupun nasional, dan bagaimana hal ini mempengaruhi kerja sama antar pemerintah. Namun ada alasan lain untuk ketegangan hubungan antara pemerintah pusat dan daerah, yang mungkin terkait dengan masalah prioritas pengeluaran atau perselisihan mengenai tingkat transfer antar pemerintah yang sesuai (Goodfellow, 2017). Dalam financial, menjanjikan lebih banyak otonomi kepada pemerintah daerah, pemerintah pusat pada saat yang sama dapat memperkuat monitoring, sehingga meningkatkan kapasitasnya untuk mengurangi pengeluaran publik yang tidak efektif. Fungsi kontrolnya mungkin lebih mudah dilaksanakan dengan tidak memiliki banyak string untuk ditarik. Dalam perspektif ini, hubungan saat ini antara pemerintah pusat dan daerah dapat dirangkum dalam rumus: tanggung jawab sentralisasi (keuangan) yang memusatkan (Elander \& Montin, 1990). Maka berdasarkan uraian diatas tujuan dari tulisan ini untuk menganalisis pada manajemen bencana antara pemerintah pusat dan pemerintah daerah dalam penanganan pandemic COVID-19 di Indonesia.

\section{Metode}

Penelitian ini menggunakan metode kajian literatur dengan menelaah data-data didalam naskah yang khusus kesiapan Indonesia dan beberapa negara dalam menanggulagi COVID-19. Metode kajian literatur sangat relevan digunakan untuk menyajikan perkembangan terbaru atau pemikiran-pemikiran terkini terkait topik tertentu (Galvan \& Galvan, 2017). Selain itu Pautasso (2013) mengungkapkan sedikitnya 10 aturan terkait metode kajian literatur di mana salah satunya adalah aturan kritis dan konsisten yaitu menekankan pada kemampuan pengkaji literatur tidak saja sekadar 
memaparkan ringkasan literatur, tetapi melainkan membahas literatur-literatur tersebut secara kritis dengan mengungkapkan fokus pembahasan, metode, hingga research gap. Kajian literatur sistematis (systematic literature review) merupakan salah satu pendekatan metode kajian literatur dengan memaparkan prosedur pemilihan kriteria publikasi dan/atau literatur yang dikaji dengan tujuan untuk mendapat gambaran yang luas terkait topik atau isu tertentu.

Kajian literatur sistematis ini awalnya digunakan untuk mengkaji kebijakan di bidang kesehatan di era tahun 80 dan 90an, dengan menganalisis temuan-temuan empiris sebelum membuat sebuah kebijakan (Ridley, 2012). Prosedur kajian literatur sistematis, secara umum, adalah sebagai berikut: (1) Penelusuran literatur dilakukan secara jelas dan transparan; (2) Kriteria pemilihan literatur bisa diawali dengan pembacaan terhadap judul, abstrak, lalu kemudian; (3) Pembacaan literatur secara menyeluruh (seluruh kegiatan ini harus tercatat); (4) Peneliti memberikan penilaian baik atau buruk, relevan atau tidak relevannya literatur terhadap tujuan dari kajian literatur yang dilakukan; (5) Prosedur ekstraksi data berdasarkan kriteria yang telah ditetapkan dari hasil penelusuran; (6) Prosedur sintesis dan analisis data dengan metode koding dan/atau klaster; dan (7) Proses interpretasi data dan kesimpulan.

\section{Hasil Dan Pembahasan}

Prinsip-prinsip yang berhubungan dengan penugasan tanggung jawab Pada dasarnya prinsip-prinsip interaksi antara pemerintah pusat maupun pemerintah daerah memiliki tanggung jawab dalam melaksanakan roda pemerintahan sesuai dengan kapasitasnya masing-masing. Adapun prinsip-prinsip ini meliputi dari prinsip subtantif yang lebih menekankan kepada penugasan tanggung jawab yang berfokus pada pengelolaan pemerintahan sendiri, mengurus atas legalitas dalam pelaksanaan kebijakan, hal ini menjadi menjelaskna bahwasanya baik pemerintah pusat maupun pemerintah daerah harus mempunyai komunikasi yang baik dalam menangani sebuah permasalahan baik dalam kondisi tidak kondusif.

Selanjutnya prinsip kedua lebih menekankan kepada prinsip instrumental yang memfokuskan dalam relasi hubungan antara pemerintah daearah dan pemerintah pusat dengan memiliki etika publik yang baik seperti kerjasama, saling menukarkan informasi, memiliki kajian sesuai aturan terhadap masing-masing pemerintah dalam menetapkan kondisi keputusan di lingkungannya masing-masing. Hal ini sangat penting karena 
berkenaan dalam pengaturan kerjasama antara pemerintah daerah dan pemerintah pusat sehingga terhindar klaim-klaim tumpang tindih kebijakan yang dilaksanakan.

Dalam penaggulangan wabah COVID-19 di indonesia seharusnya melakukan komunikasi sehingga tidak ada kesenjangan publik dimana masyarakat bisa memberikan penilaian terhadap setiap pernyataan-pernyataan baik pemerintah pusat maupun pemerinta daerah ketika akan memberikan informasi kepada masyarakat. Pemerintah pusat harus memberi contoh yang baik kepada pemerintah daerah dengan cara memberikan hak dan wewenang sepenuhya dalam penanganan COVID-19, sebgaiamana diketahui bahwasanya letak geografis memiliki karakteristik yang pemerintah pusat tidak memahaminya, pemerintah pusat seharusnya membentuk badan pengawas daaerah penanggangan COVID-19 dalam hal yang ke subtantif seperti yang dilakukan beberapa daerah dalam melakukan karantina wilayah, kemudian pemerintah daerah menjalin komunikasi yang baik dengan memberikan report terhadap situasi dan kondisi dengan memegang prinsip subtantif antara pemerintah daerah dan pemerintah pusat.

Kemudian prinsip intrumental dalam penanggangan COVID-19 anatara pemerintah pusat dan pemerintah daerah melakukan kajian yang srategis dalam penanggangan COVID-19, selanjutnya kajian terhadap faktor yang mempengaruhi di beberapa wilayah indonesia penanggangan COVID-19 serta memperhatikan klaim-klaim terhadap penanggangan COVID-19 antara pemerintah pusat dan pemerintah daerah sehingga data yang diterima oleh publik sesuai yang diharapkan karena mempunyai visi misi dan sama, sehingga intrumental dalam pelaksanaannya berjalan dengan baik sesuai dengan manajemen bencana penanggangan COVID-19 yang telah sukses dilakukan beberapa negara laian seperti singapura, china, korea selatan. Prinsip intrumental merupakan alat pemerintah daerah dan pemerintah pusat dalam menentukan kebijakan yang akan dilaksanakan.

Interaksi antara pemerintah daerah dan pemerintah pusat untuk mencapai tujuan yang sama untuk menyelesaikan penanggangan COVID-19 yang semakin tidak kondusif, maka hal ini diperlukan leadership antara pemerintah pusat dan pemerintah dangan mempertimbangkan dampak-dampak yang akan terjadi, selain itu prinsip interaksi ini juga dilakukan dengan syarat yang sangat tanggung jawab untuk dilaksanakan ketika sebuah prinsip terhadap manajemen penanggangan COVID-19 sudah siap diimplementasikan secara baik. Kemudian berdasarkan teori Lopez (2007) Prinsipprinsip yang berhubungan dengan penugasan tanggung jawab yaitu 


\section{Local Self-Government}

Local Self Government atau pemerintahan lokal daerah dalam sistem pemerintahan daerah di Indonesia merupakan semua daerah dengan berbagai urusan otonomi yang dapat mengurus rumah tangga sendiri. Hak otonom dalam Local Self Government tentunya harus berada dalam kerangka sistem pemerintahan negara. Didalam Local Self Government tidak hanya memiliki dimensi hukum dan politik, namun memiliki konotasi sosiologis, yang secara langsung memengaruhi kehidupan komunitas dalam suatu wilayah yang dibatasi (Pejanovic, 2014). Dalam penanganan COVID 19 seharusnya daerah lebih memahami terhadap kondisi lingkungannnya, kemudian kewenangan untuk mengatur dari faktor ekonomi, faktor sosial seperti kebutuhan akan kesejahteraan masyarakat terhadap kesejahteraan pelaku usaha (UMKM), kemudian membatasi aktivitas manusia di tempat umum seperti Social Distance, pembatasan area-area tertentu hingga pemberlakuan PSBB yang memang sudah di anggap urgent oleh Pemerintah Daerah.

Walaupun pemerintahan daerah melaksanakan Local Self Government memiliki kewenangan untuk mengatur dan mengurus urusan pemerintahan yang menjadi urusan rumah tangganya akan tetapi kedudukannya tetap merupakan subsistem dari sistem pemerintahan Negara. Dalam penangan COVID 19 ini pun harus memiliki koordinasi dan data yang jelas dalam melakukan komunikasi Setiap Gusus Penanganan COVID 19 di Indonesia. Kemudian bentuk pemerintahan daerah Local Self Government merupakan konsekuensi dari dianutnya asas desentralisasi dalam penyelenggaraan pemerintahan negara. Tentunya penangananan COVID 19 ini memiliki regulasi dan aturan yang cukup matang dalam pelaksanaannya yang telah di atur oleh pemerintah pusta dan di uraikan ke pemerintah daerah dalam implementasinya.

Pemberlakuan undang-undang dibentuk pemerintahan daerah tertentu dan selanjutnya daerah tersebut diserahi kewenangan untuk mengurus urusan pemerintahan tertentu dan pada perkembangannya dapat dipecah atau dimekarkan menjadi beberapa daerah tertentu sebagai turunan yang sistematis. Sebaliknya berdasarkan undang-undang daerah dimaksud dapat digabungkan dengan daerah lain atau bahkan dapat dihapuskan jika ternyata dalam perkembangannya daerah tersebut dipandang tidak mampu mengurus urusan pemerintahan yang menjadi urusan rumah tangganya, maka pemerintah pusat bisa menagambil alih wewenang tersebut. Hak warga negara untuk berpartisipasi dalam pelaksanaan urusan publik adalah salah satu prinsip demokrasi yang dimiliki bersama 
semua daerah. Keberadaan otoritas lokal dengan tanggung jawab nyata adalah prasyarat untuk administrasi yang efektif dan dekat dengan warga negara.

\section{Legality Principle}

Legalitas dapat didefinisikan sebagai suatu tindakan, perjanjian, atau kontrak yang konsisten dengan hukum atau keadaan menjadi sah atau melanggar hukum dalam yurisdiksi tertentu. Prinsip hukum bahwa seorang terdakwa tidak dapat dituntut atas suatu tindakan yang tidak dinyatakan sebagai kejahatan dalam yurisdiksi itu sebenarnya tentang Prinsip legalitas yang merupakan bagian dari keseluruhan konsep legalitas. Legality Principle atau Prinsip legalitas adalah produk legalitas yang mengharuskan semua hukum menjadi jelas, dapat dipastikan, dan tidak retrospektif. Ini mensyaratkan para pembuat keputusan untuk menyelesaikan perselisihan dengan menerapkan aturan hukum yang telah di laksanakan sebelumnya serta tidak mengubah situasi hukum secara retrospektif dengan penyimpangan diskresi dari hukum yang berlaku. Penanganan COVID 19 di Indonesia telah menerbitkan sejumlah pprisip legalitas berupa produk hukum berkenaan aturan, regulasi, protokol kesehatan, standart operasional pencegahan dan sebagainya.

Prinsip legalitas dalam penanganan COVID-19 ini memiliki relevansi khusus dalam hukum yang mengatur demi pencegahan COVID-19. Dalam produk legalitas dapat dilihat dalam sanksi pidana untuk tindakan atau kelalaian yang tindak pidana pada saat saat ini diterapkan. Prinsip legalitas ini juga dianggap urgent ketika dilanggar ketika sanksi untuk kejahatan tertentu ditingkatkan dengan efek retrospektif. Hal tersebut sesuai menurut Stoian \& Draghici (2015) legalitas merupakan prinsip urgensi bagi negara modern, prinsip legalitas telah berkembang bersama dengan sistem legislatif saat ini sebagai jaminan efisiensi mereka dan telah menjadi prasyarat utama dalam elaborasi dan penegakan hukum. Prinsip legalitas memperoleh pengakuan yang semakin meningkat dalam hukum dan secara tegas berkontribusi untuk membuat efisien kegiatan pengambilan keputusan otoritas public (Varuhas, 2020).

\section{General Competence Clause}

General Competence Clause (GCC) merupakan kewenangan daerah disebuah kabupaten maupun kota dapat melakukan intervensi pada sebuah kebijakan dimana wilayah tersebut dapat dievaluasi. Ini merupakan sebuah kepentingan ini mencerminkan pendekatan aktor yang memungkinkan, sampai batas tertentu, melampaui atau 
memperluas kekuasaan yang secara ketat dikaitkan dengan hukum yang berlaku; dengan demikian kemungkinan untuk membenarkan keputusan untuk membuat layanan publik lokal, pemberian subsidi atau bantuan material, pelaksanaan pekerjaan. Pada penanganan COVID 19 ini pemerintah pusat telah melakukan intervensi disetiap daerah agar taat pada regulasi dan kebijakan yang di buat oleh pemerintah pusat. Intervensi ini bertujuan mempercepat penanganan COVID 19 agar tidak terjadinya kesenjangan kebijakan antara pemerintah daerah maupun pemerintah pusat. Pemberian kewenangan antar pemerintah pusat kepada Pemerintah Daerah, pemerintah pusat mendorong pengambilan risiko kepada Pemerintah Daerah (Osarchuk, 2013). Dalam memberlakukan GCC, Pemerintah Pusat bermaksud untuk menghilangkan ketidakpastian yang telah muncul, dan disesuaikan dengan kebutuhan. Serta memperluas layanan dan dukungan ke area baru (Said, 2018).

Pada kenyataannya General Competence Clause ini sangat sulit diterapkan dalam penanganan COVID 19, dikarenakan COVID 19 ini bersifat wabah virus dimana pemetaan terhadap potensi penyebarannya sulit di deteksi. General Competence Clause diperlukan untuk melihat langkah-langkah strategis serta program yang telah di lakukan pemerintah pusat dan pemerintah daerah sesuai dengan produk hukum dan prinsip legalitas dalam melaksanakan protokol kesehatan dunia maupun protocol kesehatan kementerian kesehatan republik Indonesia. Saat ini program yang telah dilaksanakan sesuai dengan protocol kesehatan oleh Kementerian Kesehatan yaitu Social Distance, Physical Distance, Pembatasan Sosial Berskla Besar (PSBB) sedangkan di beberapa pemerintah daerah menerapkan system karantina wilayah. Di implementasikan GCC sehingga pemerintah daerah mengambil keputusan tentang semua urusan yang relevan dengan masyarakat dalam kerangka undang-undang yang berasal dari tingkat pemerintahan yang lebih tinggi (Gerardin, 2016). Konstitusi dan hukum kasus konstitusional memberikan "jaminan institusional" kepada otoritas lokal Praktek ini sangat meningkatkan otonomi pemerintah daerah dan pelaksanaan penuh tanggung jawab dalam layanan yang diberikan kepada mereka oleh undang-undang.

\section{Subsidiarity Principle}

Prinsip Subsidiaritas merupakan prinsip organisasi sosial yang berpendapat bahwa masalah sosial dan politik harus ditangani pada tingkat paling cepat (atau lokal) yang konsisten dengan resolusi pemerintah daerah. Prinsip ini menekankan pada daya 
tanggap pada pemerintah daerah dalam percepatan penanganan COVID 19 di Indonesia pada umumnya keterlambatan dalam menghadapi wabah tersebut, akan tetapi kebijakan dari pemerintah pusat menunjuk setiap Badan gugus dalam percepatan penanganan COVID 19 telah di anggap tepat, karena kewenangan daerah yang mampu mendeteksi secara kronologi penanganan COVID 19. Badan gugus COVID 19 di setiap daerah yang telah dibentuk akan menjadi titik dalam mengatasi masalah sosial yang terjadi pada masyarakat selama wabah ini belum terhenti yang menyebabkan mempengaruhi dari sector ekonomi, politik serta budaya. Penanganan ini dimaksud dalam manajemen bencana yang telah dibahas sebelumnya agar manajemen yang dilaksanakan oleh badan gugus penanganan COVID 19 bisa segera berakhir dengan mengurangi korban yang meninggal secara signifikan. Manajemen Bencana diharapkan dapat menurunkan angka kematian korban akibat bencana (Emaliyawati et al, 2016; Paidi, 2012).

\section{Delegation of Competences}

Delegation of Competences yang di maksud sebuah keterwakilan dalam memberdayakan orang lain untuk membuat keputusan, melakukan tugas atau mengambil tanggung jawab untuk menyelesaikan proyek atau peran pekerjaan. Delegasi kompetensi ini sangat penting pada keterampilan manajerial yang utama. Tetapi nilai pendelegasian jauh lebih dari sekadar membentuk satu aspek keterampilan dasar manajemen dan pengawasan. Belajar mendelegasikan meningkatkan produktivitas dan membuat manajer dan penyelesaikan secara signifikan lebih produktif.

Mendelegasikan tugas dapat menjadi kompetensi yang kompleks untuk dikuasai pelaksan tugas pada badan gugus penanganan wabah COVID 19. Faktanya kompetensi yang dihadapi sebagian satuan tugas dalam upaya pembuktian amanah yang telah diberikan. Setelah semuanya di tunjuk dan didelegasikan, satuan tugas kehilangan kendali dan bagi banyak orang itu adalah perasaan tidak nyaman kemudian keresahan masyarakat masyarakat terhadap wabah COVID 19. Tetapi pada akhirnya, mendelegasikan kepada anggota tim bekerja untuk membuat satuan lebih produktif setelah adanya penelian masyarakat, kemudian memberikan kesempatan anggota tim kesempatan untuk tumbuh secara profesional dan menerapkan keterampilan untuk tugas-tugas baru dan menantang.

Transformasi dari kontributor individu menjadi satuan tugas COVID 19 merupakan salah satu yang paling sulit dilakukan selama tanggung jawab profesional. Selain itu, kinerja satuan tugas pada akhirnya menjadi faktor utama dalam berbagai 
bidang yang sangat penting yang semuanya berdampak pada keselamatan masyarakat. Kinerja satuan tugas mempengaruhi retensi anggota, produktivitas, keterlibatan, kualitas, dan sejumlah hal penting lainnya yaitu tenaga medis. Satuan tugas COVID 19 menjadi lebih produktif dan efektif harus menjadi prioritas untuk setiap program pengembangan karyawan, dan pendelegasian harus menjadi kompetensi.

\section{Kesimpulan}

Hubungan pemerintah pusat dan pemerintah daerah pada mempunyai prinsip atas kewenangan dan tanggung jawab dalam melaksanakan manajemen bencana COVID 19 harus sesuai dengan aturan regulasi yang ada sesuai dengan prinsip-prinsip interaksi kewenangan daerah baik pusat maupun daerah. hal ini bertujuan untuk menghindari kurangnya koordinasi yang selama ini kurang baik didalam penanganan COVID 19 di Indonesia. Akan tetapi perlu diperhatikan bahwasanya didalam manajemen bencana perlu memperhatikan COVID hingga menyebar luar ke seluruh indonesia sebagai bentuk evaluasi dalam penanganan bencana terhadap virus menular ini. Penulis juga menekankan pada hubungan pemerintah pusat dan pemerintah daerah agar bisa memaksimalkan dalam persiapan serta pelaksanaan serta evaluasi kebijakan yang telah dilaksanakan penanganan waba bencana COVID 19 di indonesia.

Prinsip-prinsip yang berhubungan dengan penugasan tanggung jawab sesuai kewenangannya harus memiliki indikator penyesuaian terhadap lingkungan yang ada dikarenakan penanganan wabah tersebut di hambat oleh letak geografis indonesia yang merupakan negara kepulauan, selain itu perlu juga dari satuan tugas gugus percepatan penanganan COVID 19 baik di tingkah daerah maupun tingkat nasional harus memiliki manajemen yang strategi yang cepat dan tanggap agar tidak memperburuk keadaan dalam memutuskan rantai COVID 19. Terlebih birokrasi di indonesia sangat buruk didalam membuat regulasi serta manajemen dalam penanganan COVID 19 ini harus di antisipasi dengan baik agar tidak memunculkan keresahan masyarakat atas kebijakan-kebijakan yang dibuat kedepannya.

\section{Daftar Pustaka}

Adhikari, B., \& Budhathoki, S. S. (2020). Silver-lining in the Time of Mayhem: The Role of Local Governments of Nepal During the COVID-19 Pandemic. JNMA: Journal of the Nepal Medical Association, 58(231), 960. 
Anderson, S. E., Buntaine, M. T., Liu, M., \& Zhang, B. (2019). Non-governmental monitoring of local governments increases compliance with central mandates: a national-scale field experiment in China.American Journal of Political Science, 63(3), 626-643.

Carter, W. N. (2008). Disaster management: A disaster manager's handbook.

Dzigbede, K. D., Gehl, S. B., \& Willoughby, K. (2020). Disaster resiliency of US local governments: Insights to strengthen local response and recovery from the COVID-19 pandemic. Public administration review, 80(4), 634-643.

Elander, I., \& Montin, S. (1990). Decentralisation and Control: central-local government relations in Sweden. Policy \& Politics, 18(3), 165-180.

Emaliyawati, E., Prawesti, A., Yosep, I., \& Ibrahim, K. (2016). Manajemen Mitigasi Bencana dengan Teknologi Informasi di Kabupaten Ciamis. Jurnal Keperawatan Padjadjaran, 4(1).

Galvan, J. L., \& Galvan, M. C. (2017). Writing literature reviews: A guide for students of the social and behavioral sciences. Routledge.

Gerardin, N. (2016). The Goal of Simplification in the Recent Reforms of Local Government: The Case of the General Responsibility Clause. Revue francaise dadministration publique, (1), 95-104.

Goodfellow, T. (2017). Central-Local Government Roles and Relationships in Property Taxation.

Grigg, N. S. (1988). Infrastructure engineering and management.

Husein, R. (2014). Bencana di Indonesia dan Pergeseran Paradigma Penanggulangan Bencana: Catatan Ringkasan. Universitas Muhamadiah Yogyakarta (UMY).

Lee, K. H., Yi, W. H., \& Yang, W. J. (2016). A study on risk analysis of social disaster. Journal of Korean Society of Disaster and Security, 9(2), 15-21.

López, A. N. (2007). The relationship between central and local authorities. Report of the European Committee on Local and Regional Democracy, Council of Europe.

MacLaren, G., Fisher, D., \& Brodie, D. (2020). Preparing for the most critically ill patients with COVID-19: the potential role of extracorporeal membrane oxygenation. Jama, 323(13), 1245-1246.

Modjo, M. I. (2020). Memetakan Jalan Penguatan Ekonomi Pasca Pandemi. Jurnal Perencanaan Pembangunan: The Indonesian Journal of Development Planning, 4(2), 103-116. 
Osarchuk, A. M. (2013). An Argument for Public Health and Doctrinal Clarity: Why the Supreme Court Should Overturn RJ Reynolds v. FDA. NYU Ann. Surv. Am. L., 69, 265.

Paidi, P. (2012). Pengelolaan Manajemen Risiko Bencana Alam Di Indonesia. Majalah Ilmiah Widya.

Pautasso, M. (2013). Ten simple rules for writing a literature review. PLoS computational biology, 9(7), e1003149.

Pejanovic, M. (2014). Local Self-Government: A Must for Democracy, Civil Society and EU Integration. Peacebuilding and Civil Society in Bosnia-Herzegovina. Ten Years after Dayton/editor M. Fisher-Munster.: Lit-Verlag-P, 215-229.

Putra, A., \& Handoko, T. (2021). Komunikasi Pemerintah Pusat Dan Pemerintah Daerah: Kasus Dinamika Pelaksanaan Local Lockdown Dalam Mencegah Penyebaran COVID-19. Jurnal Administrasi Politik dan Sosial, 2(1), 1-15.

Rahmi, Y., \& Satria, A. (2013). Analisis Hubungan Tingkat Kerentanan Masyarakat Pesisir Terhadap Bencana dengan Upaya Pengurangan Risiko Bencana (PRB). Jurnal Penyuluhan, 9(2).

Ridley, D. (2012). The literature review: A step-by-step guide for students.

Said, A. L. (2018). Corporate Social Responsibility dalam Perspektif Governance. Deepublish.

Setiawan, R., \& Mahadiansar, M. (2020). Forecasting analysis: The Riau Islands local government role In Covid-19 disaster management. Jurnal Studi Pemerintahan, 11(3), 301-326.

Stoian, A., \& Drăghici, T. (2015). The principle of legality, principle of public law. In International Conference „,Knowledge-Based Organization (No. 2).

Tangcharoensathien, V., Bassett, M. T., Meng, Q., \& Mills, A. (2021). Are overwhelmed health systems an inevitable consequence of covid-19? Experiences from China, Thailand, and New York State. bmj, 372.

Tierney, K. (2012). Disaster governance: Social, political, and economic dimensions. Annual Review of Environment and Resources, 37, 341-363.

Varuhas, J. N. (2020). The principle of legality. The Cambridge Law Journal, 79(3), 578614. 